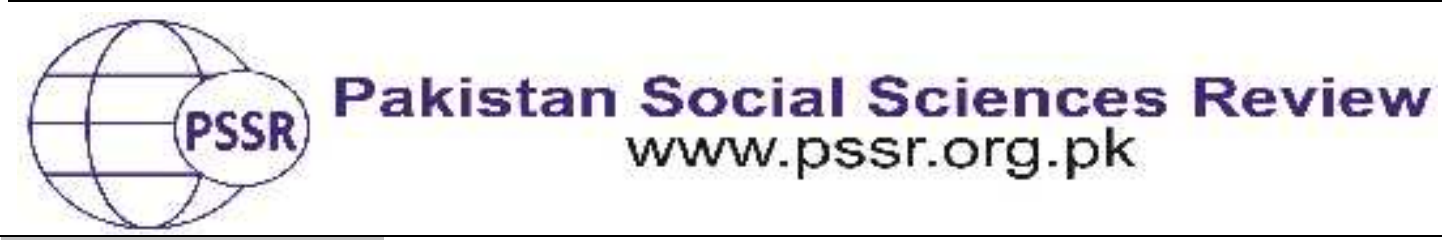

RESEARCH PAPER

\title{
Cognitive Migration in Pakistani Fiction: A Postcolonial Study
}

\author{
Dr. Zia Ahmed ${ }^{1}$ Dr. Fakhar Hussain Malik ${ }^{2}$ Dr. Adnan Tahir* 3
}

1. Professor, Department of English, Govt. Emerson College, Multan, Punjab, Pakistan

2. Lecturer, Department of English Languages and Translation Studies, Northern Border University, Saudi Arabia

3. Associate Professor, Department of English, University of Okara, Punjab, Pakistan

\begin{tabular}{|c|c|}
\hline 18 & \\
\hline $\begin{array}{l}: \\
2021 \\
2021 \\
2021\end{array}$ & $\begin{array}{l}\text { Cognitive Migration in person can pre } \\
\text { person and the writer employ their } \\
\text { purpose. This phenomenon has acquired } \\
\text { because of migrations frequency and cor }\end{array}$ \\
\hline $\begin{array}{l}\text { Keyv } \\
\text { Cogr } \\
\text { Migr } \\
\text { Postc } \\
\text { West }\end{array}$ & $\begin{array}{l}\text { phenomenon necessitates the enquiry as to } h \\
\text { characters portrayed by the Pakistani postcc } \\
\text { undergo a cognitive migration even before mi } \\
\text { land of their desire. The researcher has read the } \mathrm{s}\end{array}$ \\
\hline $\begin{array}{l}{ }^{*} \text { Cor } \\
\text { Autl }\end{array}$ & $\begin{array}{l}\text { The selected } \\
\text { sed by Kyle } \\
\text { dicated that } \\
\text { before they }\end{array}$ \\
\hline
\end{tabular}

\section{Introduction}

Migration has always been there in the human history for the sake of better sources security of human life and these have proved mostly beneficial in bringing improvement in human life. the writers from early ages to the modern ones have written on migrations and their consequent benefits. Migrations in the recent ages have become even more significant because of the knowledge and information available to the human beings about almost every part of the globe. This has further been facilitated because of the globalization, postcolonialism, and postmodernism. As they say, the world has become one village because of globalization, the humanity has more access to the knowledge about the men and materials and sounds and sights of the other parts of the world and hence the desire to migrate and imaginary about migration to the richer and greener pastures of land are also increased as well. This has been aided further by the wars, epidemics, smuggling, 
Internal and external displacements. Not only have the instances of migration increased manifold but has also developed fascination for migration to the developed parts of the world along with the increased number of restrictions and laws to prohibit migration towards the powerful countries.

The novel Exit West written on the theme of migration poses number of questions about migration and its changing patterns in the world. Brice (2020) suggests that the pattern of migration designed in Exit West is unique and novel because here the migrant does not undergo a physical journey and rather migrants "imagine a reality where migration didn't involve a journey, and instead, anyone could simply walk through a door and be in another country" (Para 1). Again, Sadaf suggests that Hamid has pointed out the difficulty of humanity's future by imagining a global future migration "through the magical portals that allow instant access to destinations around the world, challenging border divisions" (Sadaf, 2020, p. 636-646). This type of distortion introduced into the postcolonial fiction by Mohsin Hamid has opened new doors of discussion to look at the migrants' journey in a new way which may be called "literary doors into cognitive spaces of contestation as well as meaningful dialogues in a post-post-9/11 world" (Sadaf, 2020, p. 636-646) and hence making it possible to avoid the details of physical turmoil of the journey.

\section{Literature Review}

When the physical migration is seemingly possible (or even if impossible), the migrants begin to have imaginary about this migration. They begin to perceive the kind of life they would be able to have in the country that they intend to migrate. Not only this, the fears and the kind of economic hardship also become the part of this imaginary. The migrant begins to experience mental migration even before the actual migration takes place. The FASCINATION about the land the migrant intends to travel awakens his imagination and he mentally travels and seemingly faces difficulties and problems and attempts to deal with them as well. While doing do he feels pains and pangs of troubles and waves of joy as well. If at all he or she reaches the place physically, the migrants' pains and pangs and happiness may double or may reduce equally. These differences may disturb the mental and physical conditions of the migrants and their attitudes.

This new way of looking at the migrant's life, says Menger, is unique in its own way because of the device of magic doors and which also portrays about the level of difficulty in the matters of love in the life of a migrant. Menger points out that "using magical doors, they move from one place to another, a narrative device with which Hamid explores what it means to love someone while leaving behind one's home country" (Menger, 2018, p.79). The device of magic doors lends "cognitive estrangement effect" and makes it easy for the characters to see the foreign lands through their imagination. Although in the modern world of $21^{\text {st }}$ century, the device of magical doors in no way justifies in any way scientifically yet "in the novel's magic realist world, we witness a merge of the fantastical and the real, through which the characters themselves experience cognitive estrangement" (Menger, 2018, p 82). 
Sandhu (2017) stresses that the novel is not about the pains and pleasures of migration process but rather it is the end product. According to him, the novel does not talk about the 'Life-or-death' journeys not the modes of travel are described and there are no paths of travels revealed. The only thing that the novel exposes is "Just the cognitive shock of having been freshly transplanted to tough new terrains" (Sadhu, 2017, Para 5). On the other hand Gilbert (2017) terms it as a refugee experience rather than the migrants experience. Gilbert (2017) believes that the magical doors are a type of portals, which lend a sharp colour of magical realism to the novel. By using this stylistic technique, Hamid has freed himself from the description of the physical arduousness and mental trauma and instead he focuses on how his characters adapt to being interlopers in unfamiliar places" (para 5).

Early $20^{\text {th }}$ century writers took up these imaginaries of the migrants and developed fiction later termed as postmodern fiction and side by side, another wave of fiction also started to thrive termed as postcolonial fiction which was mainly allegorical. The post 9/11 world in which postmodernism lurked in and made itself felt and by multiple means. This allegorical imaginary has been used by Hamid in his novel The Reluctant Fundamentalist (2007) and later in $21^{\text {st }}$ century, he vividly employed this technique by introducing the magic doors for migration in to otherwise painful story of the protagonists of the story. These doors are definitely magical, fantastic, phantasmagorial, and expressive of the imaginary of the migrants of $21^{\text {st }}$ century.

\section{Theoretical Underpinning}

This study draws upon the cognitive migration framework provided by Kyle who claims that the stories of migrants may be apparently same, yet every migrant story has its individual flavor and is because of the fact that "before any individual departs, they typically experiment with the decision many times in their minds, imagining a different future in a distant land" (Kyle, 2020, para 4). Migration, therefore, is not simply the matter of physical migration or migration of the body but also the migration in imagination. Human mind is, according to Kyle, capable of migration on its own prior to any physical movement of the body. "A migrant doesn't just imagine a new life abroad but actually begins a cognitive resettlement before the move and even before a decision to leave" (Kyle, 2020, para 6). This study, therefore, becomes an exploration into the imaginative or mental process that begin to shape up the mind of the migrants and they develop a cognition into the intended land and culture they want to migrate to. Kyle says. "The concept of cognitive migration is an attempt to sensitize us to the crossing of the mental threshold in which we begin to move from mere imagination to making a place feel real" (Kyle, 2020, para 9). Tillich has also pronounced that there is an essential relationship between migration in person and migration by mind. He has claimed that "human mental creativity and man's migrating power belong together" (Tillich, 2020, p. 295). He basis his claim on his psychological analysis that "any theoretical description of the way in which human mind functions shows clearly that it is its power and 
dynamic nature to transcend any given actuality... to which it belongs, and from which it is at the same time separated as an individual self" (Tillich, 2020, p. 296). Tillich terms all these cognitive migrants as intellectual or social nomads residing in big metropolises rather than deserts and are capable of concocting stories from their past instead of designing some new past for them. these are in fact "futurists by definition, trying to escape any present" (Tillich, 2020, p. 297).

\section{Magic Doors in Exit West and Cognitive Migration}

For a mental migration process, the writer needs to develop a reason so that his character can move mentally beyond the established reasons and rational may be provide to make the dream look real so that the mind can comfortably traverse the distances in time and space and yet remain visible to the reader as if travelling with body. The writer of the novel, Exit West, has provided this opportunity to the reader by introducing mysterious 'Magic Doors' that open and close in their own way but each time help the reader experience a new world of the migrants. These doors seemingly operated by the hidden men who normally are above the laws of the state, in fact, like the sesame street, open up as one would desire, dream and fear.

The ground and the background for this mental migration is also prepared by the writer by introducing war into his novel. War being responsible for the migrations, whatever toughness they have. War forces the dislocation and migration for the people. It is war that causes pain and trouble of leaving the destruction and devastation of the place and hence one wishes to migrate to still greener pastures of the world. This makes the intended migrant to visualize what could be best waiting for him in comparison to the threat and loss of life being experienced in his life. In Exit West, Nadia and Saeed are showing feelings of this anxiety of war when Nadia feels that "the impending descent of their city into the abyss would come before they realized that they had lost the chance" (Hamid, 2017, p. 22).

As a matter of fact, the migrant begins to dream the fulfillment of his wishes when there is a chance of migration. In the related discussions, the migrant would think of the places and territories never visited but wished for along with the justifications or the reason of the visit. For example, during the initial discussions about their travels, Nadia and Saeed reveal the desire of travel to their cherished dream lands. Saeed's question about the dream of travels is answered as follows,

"Have you ever traveled abroad?" He shook his head. "I want to." "Me too." "Where would you go?" She considered him for a while. "Cuba." "Cuba! Why?" "I don't know. It makes me think of music and beautiful old buildings and the sea." "Sounds perfect." "And you? Where would you pick? One place." "Chile." "So we both want to go to Latin America." (Hamid, 2017, p. 24)

This dream of going to Latin America or Chile is being visualized in the passage where the protagonists see themselves in a refugee camp after having crossed the magic door. The magic door is a device used by the writer to give the colour of imaginative displacement and make it feel possible but only when one is 
able to revive one's belief in tale of the yore where such magical devices were employed to show where something was not possible as per human capacity that was put on the magical world. These doors are also, in the modern sense giving an idea of some impoverished arrangement of illegal travel to one or the other parts of the world which the writer has left on the reader to imagine and understand because he provides no clues about the travel and instead makes the reader believe that in reality there was a magic door. So, I contend that the magic door is nothing but a flight of our imagination where the migrant can visualize through his mind about the new places and people which in turn is termed as mental or cognitive migration.

The very first black door that comes the way of Nadia and Saeed proves a game changer and a shift in the entire discourse of life of both of these people, is, in fact, emblematic of the cognitive nature of their migration as it is altogether imaginative and represents a direct shift from one set of circumstances to another without engaging in the process of months of travels to experience the physical and geographical change. This was only possible through an imaginative or a cognitive experience. This nature of the change is reflected in the following word,

Nadia, ... approached the door, and drawing close she was struck by its darkness, its opacity, the way that it did not reveal what was on the other side, and also did not reflect what was on this side, and so felt equally like a beginning and an end ... (Hamid, 2017, p. 102-103)

When Nadia had emerged on other side of the door, she found herself in a washroom but felt bruised, very soon she found that Saeed was emerging from another door which was black while all other doors were not black. Saeed is also shown making a reverse discourse back to the door. This is suggestive as if it were possible to enter and exit through the magic door as and when wished which again is another mode of migration being imaginary and cognitive. For example, "she saw Saeed pivot back to the door, as though he wished maybe to reverse course and return through it" (Hamid, 2017, 104-105).

This visualization gets even stronger when they begin to realize about the future that could wait for them being a refugee. So they found themselves among the refugees of multiple hues and colors who were bound to become one community in order to face the harsh realities of the migrants life who had become homeless yet there were evil mongering people as well who were bent upon causing loss of property and honour all the time. This visualization refers back to the physical presence of the characters as well when the comparison is established between regarding color and style of the people in refugee camp and the local country people. Hamid says,

They walked away from the beach club and in the lee of a hill they saw what looked like a refugee camp, with hundreds of tents and lean-tos and people of many colors and hues - many colors and hues but mostly falling within a band of brown that ranged from dark chocolate to milky tea (Hamid, 2017, p.106). 
These set of difficulties and non-happy prospects of life makes the protagonist think and dream about better and improved set of circumstances but "the doors to richer destinations, were heavily guarded" (Hamid, 2017, 106). The possible difficulties are visualized by Nadia and Saeed about their stay with the stranger people and at stranger places. It was not like boarding a plane and landing into a safer heaven but rather a journey studded with obstacles and psychological issues. The first feel is that of refugees who have occupied all places on roads, sidewalks and other boundaries. An effort to stabilize life is witnessed but for most of them it is a problematic situation where safety and security of food and settlement is just like the refugees on the verge of the breaking down. The precariousness of the situation made life uneasy and tense and so many were peering to all possibilities and many "others stared out at the city with what looked like anger, or surprise, or supplication, or envy. Others didn't move at all: stunned, maybe, or resting. Possibly dying. Saeed and Nadia had to be careful when making turns not to run over an outstretched arm or leg" (Hamid, 2017, p. 27).

The magic door again works and brings the minds of Nadia and Saeed to another new imagination. All this begins with the fresh mental migration via the exploration of a new magic door. "Without warning people began to rush out of the camp and Saeed and Nadia heard a rumour that a new door out had been found, a door to Germany, and so they ran too, in the middle of the crowd initially, but striding so swiftly, so they were soon closer to the front" (Hamid, 2017, p. 112). But this time there was less of a going back and more of moving forward because Saeed discovered that there was no door now to take them back. The interplay of door keeps on going and working and as a result, new venues could be found. This was possible only through the working of the mind. It was a pretty difficult to find such places and get them working as per will and wish of the migrants. One level of difficulty is the financial and social but the other level of difficulty is the fear of being stuck and never moving towards the desired destination. So, the worry and anxiety, makes Saeed and Nadia to be on guards and all time thinking about their new mental migration. Very soon they found out a house with guards which must be a door to some richer destination as the doors left unguarded were the traps or led to some desolated unwanted place "and Saeed and Nadia had never before been relieved to see the guards on the island, but they were now (Hamid, 2017, p. 116).

The writer constantly connects with reality as well to keep a balance of the fictional environment. For example, Nadia listens to the prayer call and immediately feels fear of the hard liners at home in her own country. She feels upset. "In the morning they heard in a distance someone making a call to prayer, at dawn, perhaps over a commandeered Karaoke machine, and Nadia was alarmed, waking from a dream and thinking for a second that she was back home in their own city, with the militants, before recalling where she really was, ..." (Hamid, 2017, 128). This passage reflects that a process of transportation is in place and that very process helps the characters navigate mentally from one geography to the other. And again, the following lines indicate that the migration is being foreseen and the mental travels are being made when Saeed asks Nadia about her future life as to what and where 
she would like to live. "That night he asked her what the life of her dreams would look like, whether it would be in a metropolis or in the country side, and she asked whether he could see them settling in London and not leaving, and they discussed how houses such as the one they were occupying might be divided into proper apartments, and also how they might start over someplace else, elsewhere in this city, or in a city far away" (Hamid, 2017, 136). Again, the very next passage takes Nadia in a different location, just mentally. But the spell breaks and shakes us from our sleep because of the magic doors when both the protagonists see themselves in the country of their origin and making plans of flying to some next destination. This flight would again be cognitive and imaginative and would be made in the same as are the previous mental flights. We see the writer making his characters saying,

He nodded and said if she had an evening free he would take her, it was a sight worth seeing in this life, and she shut her eyes and said she would like that very much, and they rose and embraced and parted and did not know, then, if that evening would ever come. (Hamid, 2017, p. 230-31)

\section{Findings and Conclusion}

The above discussion helps us find that Hamid has used the technique of cognitive migration preceding the physical migration. Cognitive migration is possible for everyone because in a way all of us are migrants in nature. But we tend to visualize this migration and associate ourselves with the new set of circumstances which normally make us imagine difficulties and ultimate success. Like any other migrant, it is the dream of Nadia and Saeed to leave their country for greener pastures and so they visualize the future through their mind's eye. This becomes even necessary because of the presence of war and terroristic conditions in their country. They also have suffered because of the losses of their families and now can no more be happy in their own country. Nadia, being a woman is the special target of the misery in her country at the time when she stands in a queue and bears the physical harassment by her own people. The wish to migrate is the only option left to her and Saeed. They magic doors help them migrate cognitively and visualize themselves out of the troubled zones.

In order to make it even more imaginative and cognitive Hamid uses the mysterious black doors in order to make a huge shift possible from one part of the world to the other which was otherwise a difficult task. The very first shift from their eastern side of the world to the Western side could not have been possible without an air or sea journey. In the novel it takes only a wink of the eye and both Nadia and Saeed find themselves on a beach of Greek Island. This imaginative flight takes place many times in the novel to take them to different parts of Europe and ultimately have an experience of the life of the refugee camp and the refugee working in the western world. The time also comes when they begin to interact with other characters by giving freedom to each other. The twist in the story comes when both reunite in the end of the story to make a new plan on a cup of coffee. 


\section{References}

Brice,A.(2020). 'Exit West' author Mohsin Hamid: 'Migration is what our species does'Berkley News https://news.berkeley.edu/2020/09/01/on-the-samepage-exit-west-mohsin-hamid/

Gilbert, S. (2017). Exit West and the edge of dystopia.Culture. The Atlantic. https://www.theatlantic.com/entertainment/archive/2017/03/exitwest/518802/

Hamid, M. (2007). The reluctant fundamentalist. USA: Penguin Books.

Kyle, D. (2020), Migrations of the mind. All Research Spotlights. Sociology. UCDAVIS. https://sociology.ucdavis.edu/research/research-spotlight/faculty-researchspotlight/migrations-of-the-mind-david-kyle

Menger, E. (2018). What it feels like to be another: Imaginations of displacement in contemporary speculative fiction.Studies in Arts and Humanities, 4(2), 79-95. Retrieved from www.sahjournal.com

Sadaf, S. (2020). We are all migrants through time: History and geography in Mohsin Hamid's Exit West. Journal of Postcolonial Writing, 56(5), 636647.https://www.tandfonline.com/doi/abs/10.1080/17449855.2020.1820667

Sandhu, S. (2017). Exit west by Mohsin Hamid - magical vision of the refugee crisis. The ObserverMohsin Hamid Para 5 Books, The Guardian. Retrieved from https://www.theguardian.com/books/2017/mar/12/exit- west-mohsinhamid-review-refugee-crisis.

Tillich, P. (1937). Mind and migration. Social Research, 4(3), 295305.http://www.jstor.org/stable/40981563 